\title{
Pelatihan Komunikasi Mengatasi Perbedaan Persepsi Program Adiwiyata Pada Guru Sd Di Tangerang
}

\author{
Rosmawaty Hilderiah Pandjaitan ${ }^{1}$ \\ ${ }^{1}$ Magister Ilmu Komunikasi Universitas Mercu Buana, Jakarta \\ rossajeffrey@gmail.com
}

\begin{abstract}
Abstrak
Tidak mudah mendapatkan dukungan dan komitmen dari semua pihak, tentang program Adiwiyata, bila ada masalah perbedaan persepsi yang mempengaruhi sulitnya keterbukaan di antara murid, orang tua, dan guru sendiri. Hal inipun terjadi pada Sekolah Dasar Islam Amalina (SD IA) dan beberapa SD lainnya yang juga menerapkan program Adiwiyata di lingkungan sekolah mereka. Alasan inilah yang menjadi latarbelakangi dilakukannya kegiatan pelatihan ini, yang dilaksanakan di SD IA, Tangerang Selatan, pada hari Rabu, 12 Februari 2020, dihadiri 25 orang peserta dari 11 SD berbeda. Tujuannya adalah meningkatkan pengetahuan dan kreativitas komunikasi para guru, tentang cara mengatasi perbedaan persepsi mengenai saluran adopsi inovasi program Adiwiyata pada murid, orang tua, maupun guru sendiri. Menggunakan metode ceramah, demonstrasi, tanya jawab, dan praktek langsung.

Hasilnya yaitu : Satu, mayoritas peserta mengerti, menerima, dan menilai PKM ini bermanfaat, karena memberikan pemahaman yang selama ini kurang disadari.; Dua, pelatihan ini membuka wawasan tentang 9 faktor penyebab perbedaan persepsi akan saluran komunikasi apdopsi inovasi program Adiwiyata, seperti faktor manusia, faktor kesadaran dan peduli, komitmen, ketidaksiapan, perilaku, informasi, pengetahuan, pelatihan, dan keuangan.; Tiga, pelatihan ini membangun kesadaran mayoritas peserta tentang cara komunikasi para guru SD yang masih kurang variatif, dan cenderung lebih menyerahkan tanggungjawab hanya kepada kepala sekolah semata.
\end{abstract}

Kata Kunci : Pelatihan Komunikasi, Persepsi, Adiwiyata, Sekolah Dasar

\section{PENDAHULUAN}

Sejak tahun 2013, Sekolah Dasar Islam Amalina (SD IA) sudah menjadi sekolah Adiwiyata. Bahkan pada pada tahun 2014, mendapatkan penghargaan sebagai sekolah Adiwiyata Tingkat Kota, dan pada tahun 2015 mendapatkan penghargaan sebagai sekolah Adiwiyata Tingkat Propinsi, dan pada tahun 2016 mendapatkan penghargaan sebagai sekolah Adiwiyata Tingkat Nasional, dan pada tahun yang sama juga dipilih mewakili Indonesia dalam acara Training of Trainers on the Whole-Institution Approach to Climate Change, untuk memperkenalkan program Adiwiyata di Kantor UNESCO, Paris, seperti diakses dari https://www.antaranews.com/berita/598742/unescodakar-puji-program-sekolah-adiwiyata-indonesia. Selain itu, pada tahun 2019 mendapatkan penghargaan sebagai sekolah Adiwiyata Tingkat Mandiri. 
Ironisnya berdasarkan hasil riset Pandjaitan, Yoyoh, Suratani, dan Maria (2019), diketahui ada masalah perbedaan persepsi tentang pilihan saluran komunikasi Adiwiyata pada murid, orang tua dan guru SD IA, serta diketahui masih lemahnya keterbukaan diantara murid, orang tua (khususnya para ibu), maupun guru SD IA sendiri, tentang perbedaan persepsi mengenai ragam pilihan saluran komunikasi adopsi inovasi program adiwiyata tersebut.

Padahal SD IA menerapkan program Adiwiyata tersebut dalam sistem pendidikan full day school selama lima hari. Selain itu juga, SD IA mempunyai Visi sebagai sekolah Adiwiyata terbaik tingkat Nasional pada Tahun 2020. Disamping itu, SD IA juga aktif sebagai pembina Adiwiyata bagi sekolah lainnya di sekitar Pondok Aren, Tangerang Selatan, yang jumlahnya lebih dari sepuluh sekolah.

Jadi agar temuan masalah hasil riset Pandjaitan, Yoyoh, Suratani, dan Maria (2019) tersebut tidak menimbulkan konflik, dan program Adiwiyata pada SD IA terus mendapatkan dukungan dan komitmen dari semua pihak, baik dari murid, orang tua, dan guru sendiri, maka semua masalah tersebut harus segera diungkap, dan dicarikan solusinya. Apalagi mengingat bahwa untuk mencapai Visi SD IA, butuh dukungan, peran serta, dan komitmen, juga kesepakatan dari semua pihak. Baik dari murid, orang tua, maupun guru SD IA sendiri. Itulah sebabnya dilakukan kegiatan PKM ini bagi SD IA, yang sekaligus menjadi rasionalisasi dan urgensi kegiatan PKM ini.

Alasan inilah yang secara rasional menjadi latarbelakang sekaligus urgensi dilakukannya kegiatan PKM ini, yang mengambil tema, pelatihan komunikasi mengatasi perbedaan persepsi dan saluran komunikasi adopsi inovasi program Adiwiyata pada Guru SD IA. Selain diharapkan bermanfaat bagi SD IA, juga bermanfaat bagi SD lainnya yang juga menerapkan program Adiwiyata. Selain itu juga, ditujukan untuk membantu pemerintah, khususnya Kementrian Lingkungan Hidup dan Kehutanan (KLHK), dalam menerapkan program Adiwiyata sebagai upaya perlindungan dan pengelolaan lingkungan hidup di sekolah, seperti diatur dalam Peraturan Menteri LH Nomor 5 tahun 2013.

Seperti diungkap dalam website Kementrian Lingkungan Hidup dan Kehutanan, tidak mudah menerapkan program Adiwiyata pada lembaga pendidikan formal. Buktinya sejak tahun 2006 sampai 2019, dari sekitar 250.000 sekolah yang terdaftar di seluruh Indonesia, baru sekitar 4.305 sekolah, atau sekitar $1,722 \%$ saja sekolah yang berhasil meraih penghargaan Adiwiyata. Diantaranya yaitu, 3.477 sekolah yang berhasil meraih penghargaan Adiwiyata Nasional dan 828 sekolah yang berhasil meraih penghargaan Adiwiyata Mandiri. Bahkan dalam tahun 2019 sendiri, dari 434 sekolah yang berhasil mendapatkan penghargaan Adiwiyata, hanya 333 sekolah yang berhasil mendapatkan penghargaan Adiwiyata Nasional, dan sisanya 101 sekolah berhasil mendapatkan penghargaan Adiwiyata Mandiri. Terdiri atas 376 sekolah negeri dan 58 sekolah swasta dari 164 kota/kabupaten di 32 propinsi. Padahal menurut Kepala Badan Penyuluhan dan Pengembangan SDM KLHK, Helmi Basalamah, pada tahun 2019 lalu, terdapat 1.372 sekolah yang diusulkan oleh Dinas Lingkungan Hidup. Jumlah tersebut terdiri atas 1.196 sekolah negeri, dan 176 sekolah swasta dari 265 kota/kabupaten di 32 propinsi. Hal inipun diungkap oleh Iswari dan Suyud (2017, p.35-36), bahwa tidak mudah membuat program tersebut terus diadopsi dan dilaksanakan secara konsisten oleh semua pihak, seperti murid, guru, maupun orang tua. Demikian menurut Hidayati (2013, p.150), ada beragam alasan yang muncul.

Tidak heran bila sampai saat ini, masih banyak sekolah yang belum mampu mengadopsi program tersebut. Padahal, seperti dilaporkan oleh Menteri Lingkungan Hidup dan Kehutanan (KLHK), Siti Nurbaya, dalam acara Penghargaan Adiwiyata Tahun 2019, Jumat, 13 Desember 2019, program Adiwiyata telah berhasil mendorong adanya peningkatkan upaya perlindungan dan pengelolaan lingkungan hidup di sekolah. Misalnya saja dalam kurun waktu tahun 2006-2019, Sekolah Adiwiyata telah memberikan kontribusi berupa pengurangan timbunan sampah melalui pengelolaan sampah dengan 3R (reduce, reuse dan recycle) sejumlah 38.745 ton per tahun. Selain itu juga berkontribusi 
dalam penanaman dan pemeliharaan 322.875 pohon/tanaman, dan 64.575 lubang biopori, serta 12.915 sumur resapan. Demikian juga dalam hal membantu upaya menghemat penggunaan listrik dan air, yaitu antara $10-40 \%$ per sekolah.

Adapun Sekolah Adiwiyata yaitu, sekolah yang telah menerapkan program Adiwiyata atau sistem kurikulum yang dipadukan dengan programprogram pemeliharaan dan pengelolaan lingkungan hidup, dengan maksud untuk mewujudkan warga sekolah yang bertanggung jawab dalam upaya perlindungan dan pengelolaan lingkungan hidup melalui tata kelola sekolah yang baik untuk mendukung pembangunan berkelanjutan. Program ini sebenarnya sudah ada sejak tahun 2006 (Hadi, 2019). Awalnya dicetuskan oleh Kementerian Lingkungan Hidup, lalu dilanjutkan oleh Kementerian Lingkungan Hidup dan Kehutanan. Bertujuan mewujudkan sekolah yang peduli dan berbudaya lingkungan hidup, melalui kegiatan pembinaan, penilaian, dan pemberian penghargaan Adiwiyata kepada sekolah.

Sebagai pedoman pelaksanaannya, seperti diatur dalam Peraturan Menteri LH Nomor 5 tahun 2013 (Iswari dan Suyud, p.36). Jadi, program Adiwiyata ini bertujuan membentuk karakter peduli lingkungan, mulai dari memelihara sampai mengelolah lingkungan hidup, melalui tata kelola sekolah yang baik, untuk mendukung pembangunan berkelanjutan (Hidayati, p.150). Bahkan, oleh Kementerian Pendidikan dan Kebudayaan, karakter peduli lingkungan tersebut sudah ditetapkan menjadi bagian dari 18 karakter bangsa yang difokuskan kepada seluruh sekolah di Indonesia.

Jadi dapat ditegaskan, Adapun tujuan PKM ini yaitu : Satu, untuk membuka tabir dan menambah atau meningkatkan pengetahuan Guru SD IA dan Guru dari SD binaan mereka, tentang faktor-faktor penyebab munculnya perbedaan persepsi, pendapat, dan pilihan saluran komunikasi adopsi inovasi program adiwiyata pada anak murid, orang tua (khususnya para ibu), maupun para guru sendiri, yang juga menjadi masalah komunikasi di antara anak murid, orang tua, maupun guru sendiri.; Dua, untuk menambah atau meningkatkan pengetahuan dan kreativitas komunikasi Guru SD IA dan Guru SD binaan mereka, tentang manfaat ruang komunikasi bagi keterbukaan anak murid, orang tua, maupun guru, sebagai cara untuk mengatasi perbedaan persepsi dan pendapat, atau masalah komunikasi di antara mereka, tentang pilihan saluran komunikasi adopsi inovasi program adiwiyata.; Tiga, untuk menambah atau meningkatkan pengetahuan tentang metode dan kreativitas komunikasi guru SD dalam menggali informasi dari anak murid, orang tua, maupun guru sendiri, sebagai cara evaluasi mengenai pilihan saluran komunikasi adopsi inovasi program adiwiyata agar dapat diterima dan terus dipertahankan, baik oleh anak murid, orang tua, maupun para guru sendiri. Demikian 3 tujuan PPM ini, yang sekaligus juga menjadi urgensi dari kegiatan PPM ini.

Sebagai solusi atas semua masalah tersebut, ditawarkan 5 solusi. Disampaikan secara lisan, tertulis, maupun dengan menggunakan alat bantu berupa video dan praktek langsung dengan semua peserta yang hadir.

Solusi pertama, ditawarkan pentingnya menggali informasi dari semua pihak, baik dari murid, orang tua, maupun guru sendiri, agar diketahui fakta dan misteri informasi yang tersembunyi. Misalnya saja dengan bekerjasama dengan pihak luar, sebagai cara mengungkap fakta tentang adanya perbedaan persepsi mengenai pilihan saluran komunikasi adopsi inovasi program Adiwiyata pada anak murid, orang tua, maupun guru sendiri, yang bisa saja belum disadari oleh para Guru. Hal ini seperti dilakukan oleh Kepala Sekolah SD IA yang bekerjasama dengan Pandjaitan, Yoyoh, Suratani, dan Maria (2019).

Solusi kedua, menjelaskan tentang pengertian persepsi antar pribadi, dan faktor-faktor yang mempengaruhinya, sebagaimana dijelaskan oleh Gibson dan Donnelly (1996, p.134) dalam Rosmawaty (2010, p.63), bahwa persepsi merupakan proses kognitif yang dialami setiap orang dalam memahami lingkungannya, baik lewat penglihatan, pandangan, penghayatan, perasaan, maupun penciuman. Selain itu juga dijelaskan tentang cara membedakan persepsi manusia dan faktor-faktor 
yang mempengaruhinya, sebagaimana dikatakan oleh Mulyana (2008, p.171-175), bahwa persepsi manusia dapat dibedakan menjadi dua bagian, yaitu persepsi terhadap objek (lingkungan fisik) dan persepsi terhadap manusia (persepsi sosial).

Solusi ketiga, menjelaskan pengertian dan contoh-contoh saluran komunikasi, sebagaimana dikutip dari Rogers (1995, p.160-164), bahwa ragam saluran komunikasi dapat berupa saluran media massa (mass media channels) dan saluran antarpribadi (interpersonal channels), yang dapat menjadi alat bagi sampainya suatu pesan dari sumber ke penerima, dan merupakan alat yang dapat dipergunakan untuk membangun pengetahuan, persuasi, keputusan, penerapan, sampai konfirmasi. Seperti radio, televisi, film, dan surat kabar yang dikenal sebagai saluran media massa. Sedangkan saluran komunikasi antarpribadi yaitu, semua saluran interaksi tatap muka (face to face exchange), antara dua individu atau lebih. Selain itu, juga dijelaskan tentang perbedaan efektifitas ragam saluran interaksi tatap muka dan media massa, dimana saluran interaksi tatap muka dinilai lebih efektif dalam menghadapi khalayak yang bertahan (resistan) ataupun apatis dalam menghadapi penyebarluasan suatu inovasi, karena dapat memungkinkan pertukaran ide secara timbal-balik, sehingga dapat untuk membujuk dan mengubah ataupun membentuk sikap yang teguh. Sedangkan media massa, hanya untuk perubahan pengetahuan.

Solusi keempat, menjelaskan teknik-teknik komunikasi yang dapat dimanfaatkan oleh Guru sebagai cara untuk membangun keterbukaan anak murid, orang tua (khususnya para ibu), maupun guru sendiri, sebagai cara untuk mengatasi perbedaan persepsi dan pendapat, atau masalah komunikasi mengenai pilihan saluran komunikasi adopsi inovasi program adiwiyata agar dapat diterima oleh mereka.

Solusi kelima, menjelaskan tentang metode komunikasi yang dapat dimanfaatkan oleh guru sebagai cara untuk menggali informasi dari anak murid, orang tua, maupun sesama guru SD IA sendiri, agar dapat membantu upaya evaluasi mengenai saluran komunikasi adopsi inovasi program adiwiyata bagi anak murid, orang tua (khususnya para ibu), maupun guru sendiri. Seperti metode riset yang disarankan oleh Kriyantono (2007, p.290), yaitu metode observasi, survey atau kuesioner, wawancara, FGD, metode polling, dan eksperimen.

\section{METODE}

\section{Jenis Kegiatan}

Jenis PKM ini adalah pelatihan komunikasi, yang dileburkan dalam tema, pelatihan komunikasi mengatasi perbedaan persepsi dan pilihan saluran komunikasi adopsi inovasi program Adiwiyata pada anak murid, orang tua, dan guru SD IA Di Tangerang Selatan. Menurut Simamora (2003, p.273), yang dimaksud dengan pelatihan (training) yaitu, mengandung maksud untuk menambah dan meningkatkan pengetahuan/keterampilan serta merubah sikap/perilaku peserta ke arah yang lebih produktif. Sedangkan kreativitas yang dimaksud yaitu, dapat diartikan sebagai berikut : Satu, kemampuan menanggapi, dan memberikan jalan keluar segala pemecahan yang ada,; Dua, kemampuan melibatkan diri pada proses penemuan masalah,; Tiga, kemampuan intelegensi, gaya kognitif, dan kepribadian/motivasi,; dan Empat, kemampuan untuk menghasilkan atau mencipta sesuatu yang baru. Jadi, kreativitas ini didasari dengan: kelenturan (fleksibility), kelancaran (fluencely), kecakapan (smartly), dan kepandaian (inetellegency) (Campbell 2017, p.35).

Selain itu juga, seperti yang dikatakan oleh Rhodes (Munandar, 2004, p.20-22), bahwa kreartivitas tersebut yaitu, sebagai Four $P$ 's of Creativity : Person, Process, Press, and Product, yang menjelaskan tentang 4 aspek kreativitas, seperti : Pertama, Aspek pribadi (person), kreativitas dilihat sebagai "three facet model of creativity", yang merupakan titik pertemuan yang khas antara atribut psikologis seperti inteligensi, gaya kognitif, dan kepribadian atau motivasi. Ketiga atribut tersebut bersama-sama membantu dalam memahami latarbelakang individu menjadi kreatif.; Kedua, Aspek proses, yang menyatakan bahwa kreativitas pada dasarnya menyerupai langkah-langkah dalam metode ilmiah, meliputi seluruh proses kreatif dan ilmiah, mulai dari menemukan masalah sampai dengan menyampaikan masalah.; Ketiga, Aspek 
produk, seperti kemampuan dalam menghasilkan atau menciptakan sesuatu yang baru (yang menekankan orisinalitas) ataupun kemampuan membuat kombinasi-kombinasi baru yang mempunyai makna sosial.; dan Keempat, Aspek dorongan (press), lebih menekankan pada faktor "press" atau dorongan, baik dorongan internal (diri sendiri berupa keinginan dan hasrat untuk mencipta atau bersibuk diri secara kreatif) maupun dorongan eksternal dari lingkungan sosial psikologi.

Demikian halnya dengan PKM ini. Pada dasarnya dimaksudkan untuk menambah atau meningkatkan pengetahuan tentang faktor-faktor penyebab adanya perbedaan persepsi dan pendapat, atau masalah komunikasi tentang pilihan saluran komunikasi adopsi inovasi program Adiwiyata pada anak murid, orang tua, dan guru SD. Selain itu, untuk meningkatkan pengetahuan dan kreativitas komunikasi guru, tentang cara mengatasi perbedaan persepsi dan pilihan saluran komunikasi adopsi inovasi program Adiwiyata pada anak murid, orang tua, dan guru SD.

\section{Tempat dan Waktu Pelaksanaan}

Sesuai hasil koordinasi dengan Kepala Sekolah SD IA, Ibu Nensih Kusliawati, pelaksanaan PKM ini dilaksanakan di SD Islam Amalina. Beralamat di jalan Raya Pondok Aren, Tangerang Selatan, pada hari Rabu, 12 Februari 2020. Mulai pk. 08.30-13.00 wib, ditutup dengan makan siang dan foto Bersama, seperti tampak pada Gambar 1.

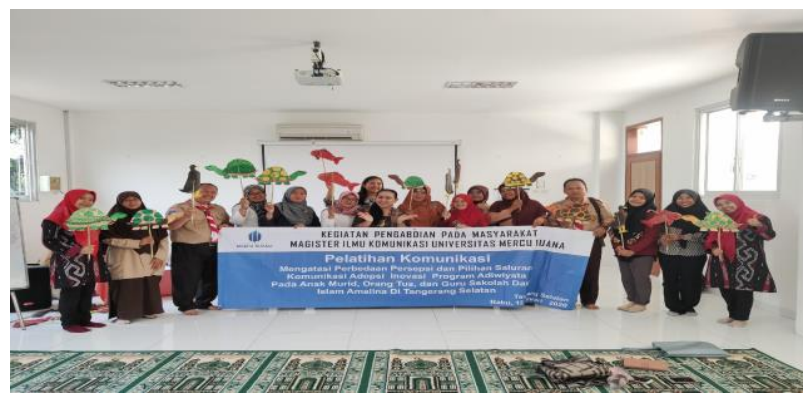

Gambar 1. Foto Bersama Peserta PKM

Sumber : Milik Pribadi Fasilitator (Rosmawaty Hilderiah Pandjaitan, 2020)

\section{Khalayak Sasaran}

Sesuai tema, sebenarnya khalayak sasaran dalam pelatihan ini yaitu, para guru SD IA. Namun Kepala Sekolah SD IA juga mengundang 10 SD binaan mereka, mengingat mereka juga peduli pada program Adiwiyata.

Adapun jumlah peserta yang hadir sebanyak 25 orang. Semuanya merupakan Guru, namun ada juga yang memiliki jabatan sebagai Kepala Sekolah. Berasal dari 11 sekolah yang berbeda. Selain dari SD IA, juga hadir para guru dari SDN Pondok Aren 01, SDS Hikari, SDS Fadilah, Madrasah Ibtidaiyah Jam'iyyatul Khair, Madrasah Ibtidaiyah Nurul Islam, Madrasah Ibtidaiyah Nurul Huda Pd. Jaya, SDN Pondok Karya, SDIP Baitul Maal, SDI Al Azhar 17 Bintaro, seperti tampak pada Tabel 1.

Tabel 1.

Nama Sekolah dan Jumlah Peserta Yang Hadir

\begin{tabular}{|c|l|c|}
\hline No & \multicolumn{1}{|c|}{ Nama Sekolah } & Jumlah \\
\hline 1 & SD Islam Amalina (SD IA) & 13 \\
\hline 2 & SDN Pondok Aren 01 & 2 \\
\hline 3 & SDN Pondok Aren 02 & 1 \\
\hline 4 & SDS Hikari & 2 \\
\hline 5 & SDS Fadilah & 1 \\
\hline 6 & $\begin{array}{l}\text { Madrasah } \\
\text { Jam'iyyatul Khair Ibtidaiyah }\end{array}$ & 1 \\
\hline 7 & $\begin{array}{l}\text { Madrasah Ibtidaiyah Nurul } \\
\text { Islam }\end{array}$ & 1 \\
\hline 8 & $\begin{array}{l}\text { Madrasah Ibtidaiyah Nurul } \\
\text { Huda Pd. Jaya }\end{array}$ & 1 \\
\hline 9 & SDN Pondok Karya & 1 \\
\hline 10 & SD Islam Plus Baitul Maal & 1 \\
\hline 11 & SD Islam Al Azhar 17 Bintaro & 1 \\
\hline
\end{tabular}

Sumber: Rosmawaty Hilderiah Pandjaitan, 2020

\section{Teknik Kegiatan}

Secara teknis, PKM ini dilaksanakan dalam lima langkah. Langkah pertama, menjelaskan latarbelakang PKM, maksud dan tujuan, serta manfaat PKM. Selain untuk membangun pemahaman bersama, juga sebagai motivasi agar semua peserta mau mendengarkan, dan bersedia fokus, serta aktif dalam pelatihan komunikasi ini. 
Langkah kedua, mengungkap fakta tentang adanya perbedaan persepsi dan pilihan saluran komunikasi adopsi inovasi program Adiwiyata pada anak murid, orang tua, dan guru SD IA di Tangerang Selatan. Sebagaimana hasil riset Pandjaitan, Yoyoh, Suratani, dan Maria (2019), yang juga sudah dipublikasikan melalui konferensi nasional di Yogyakarta, dan publikasi melalui Prosiding Konferensi Pendidikan Nasional "Strategi dan Implementasi Pendidikan Karakter pada Era Revolusi Industri 4.0", dengan ISSN: 2654-8607, p. 248-259. Langkah ketiga, menjelaskan solusi, yang dimulai dengan memberikan pengertian tentang persepsi antar pribadi, dan cara membedakan persepsi manusia serta faktor-faktor yang mempengaruhinya, juga tentang contoh-contoh saluran komunikasi media massa (mass media channels) dan saluran komunikasi antarpribadi (interpersonal channels), yang dapat menjadi alat bagi sampainya pesan Adiwiyata dari sumber ke penerima, dan merupakan alat yang dapat dipergunakan untuk membangun pengetahuan, persuasi, keputusan, penerapan, sampai konfirmasi. Selain itu juga dijelaskan tentang teknik-teknik dan metode komunikasi yang dapat dimanfaatkan oleh guru sebagai cara untuk membangun keterbukaan dan menggali informasi dari anak murid, orang tua, maupun guru sendiri, sebagai cara untuk mengatasi perbedaan persepsi dan pendapat, atau masalah komunikasi mengenai pilihan saluran komunikasi adopsi inovasi program adiwiyata agar dapat diterima, baik oleh anak murid, orang tua, maupun para guru. Langkah keempat, melakukan praktek oleh semua peserta PKM, tentang cara komunikasi dengan berbagai macam teknik dan metode, sebagai cara untuk mengatasi perbedaan persepsi dan pendapat, atau masalah komunikasi mengenai pilihan saluran komunikasi adopsi inovasi program adiwiyata agar dapat diterima, baik oleh anak murid, orang tua, maupun para guru SD IA. Terakhir langah kelima, membuka ruang tanya jawab, sebagai cara untuk menggali dan mendapatkan respon dari para peserta, dan untuk mengetahui pemahaman serta penerimaan mereka tentang informasi yang telah disampaikan.

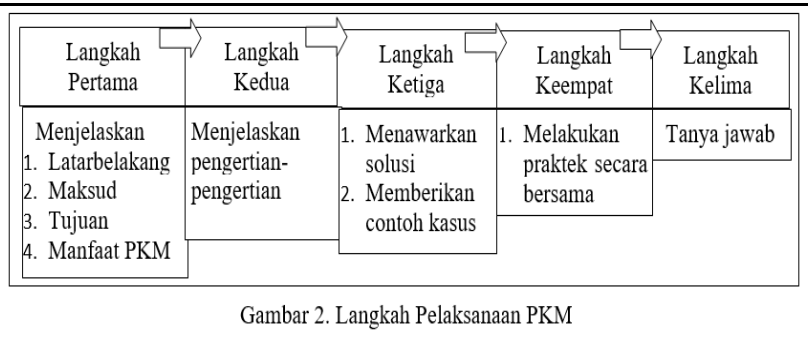

\section{Metode Pelaksanaan}

Metode pelaksanaan dilakukan dengan 4 metode. Pertama, metode ceramah, yang disampaikan secara langsung tatap muka, dengan menggunakan alat bantu seperti slide projector, dan pemutaran beberapa video sebagai contoh kasus, dengan lama ceramah sekitar 45 menit saja. Kedua, metode demonstrasi. Sesuai namanya, metode ini dilakukan dengan cara mempertontonkan, memperagakan, dan mempertunjukkan atau memperlihatkan secara langsung di hadapan para peserta PKM, dengan maksud agar lebih mudah dipahami dan ditiru. Ketiga, metode tanya jawab. Sebagai cara untuk menggali dan mendapatkan respon dari para peserta, guna mengetahui pemahaman dan penerimaan mereka tentang informasi yang disampaikan. Keempat, metode percobaan melalui praktek langsung atau eksperimen. Eksperimen adalah suatu upaya percobaan yang bersistem dan berencana (untuk membuktikan kebenaran suatu teori), namun metode eksperimen adalah metode pemberian kesempatan kepada peserta didik perorangan ataupun kelompok, untuk dilatih melakukan suatu proses atau percobaan. Demikian dalam pelatihan ini, karena sifat PKM ini adalah pelatihan komunikasi, maka sudah pasti metode ini menjadi salah satu cara yang efektif untuk melatih peserta yang hadir. Jadi semua peserta dilatih dan dites secara satu-persatu tentang pengetahuan, teknik, metode, dan kreativitas komunikasi sebagai cara untuk mengatasi perbedaan persepsi dan pendapat, atau masalah komunikasi mengenai pilihan saluran komunikasi adopsi inovasi program adiwiyata agar dapat diterima, baik oleh anak murid, orang tua, maupun para guru. 


\section{Langkah Evaluasi Pelaksanaan Program}

Mengenai langkah evaluasi sebagai cara untuk mengukur kuantitas perubahan pemahaman dan penerimaan peserta tentang informasi yang disampaikan, digunakan metode tanya jawab langsung dan kuesioner yang dibagikan pada saat sebelum dan setelah acara PKM selesai. Langkah ini dipilih, selain sebagai cara untuk mengukur efektifitas solusi, juga tingkat pengetahuan atau pemahaman peserta. Menggunakan paradigma positivistik atau dengan logika deduktif (deductive logic) (Neuman, 2007, p.140), sebagai cara untuk membangun pemahaman. Sedangkan untuk menjelaskan hasil interpretasi subyektif berdasarkan hasil observasi dan tanya jawab langsung dengan beberapa peserta, digunakan metode deskriptif kualitatif.

Guna mendapatkan jawaban yang tegas, atau sebagai cara mengukur variabel, digunakan Skala Guttman, dengan jawaban "Ya-Tidak" dan "Mengerti-Tidak Mengerti" (Sugiyono, 2013, p.96). Untuk membedakan responden, digunakan skala nominal atau kode (bukan nilai) $\mathrm{X}$ dan $\mathrm{Y}$, yang membedakan antara peserta guru laki-laki (X), dan peserta guru perempuan (Y). Teknik pengambilan sampel, digunakan probability sampling dengan teknik simple random sampling (sampel random acak sederhana) yang dilakukan berdasarkan sampling tersedia (availability sampling) (Alwi, 2015:141) atau dengan memanfaatkan subjek yang tersedia.

\section{Keberlanjutan Program}

PKM ini sebenarnya merupakan output dari penelitian Tesis Magister yang mendapat hibah Dikti pada tahun 2019, bekerjasama dengan SD IA.

\section{Partisipasi Mitra Dalam Program}

Partisipasi SD IA sebagai mitra dalam program ini cukup besar. Mulai dari mempersiapkan tempat, sound system, juga membantu mengundang para peserta PKM yang berasal dari 10 sekolah Adiwiyata. Selain itu juga membantu dalam mempersiapkan konsumsi untuk makan siang semua peserta.

\section{HASIL DAN PEMBAHASAN}

\section{Hasil}

\section{Gambaran Peserta PKM}

Sebagaimana telah dijelaskan, peserta PKM ini ada 25 orang. Berasal dari 11 SD berbeda. Diantaranya 4 dari SD Negeri, dan 7 dari SD Swasta Islam, seperti tampak pada Tabel 1. Terdiri atas 21 orang perempuan, dan 4 orang laki-laki, seperti tampak pada Tabel 2 .

Dari Tabel 2. dapat dilihat, $84 \%$ atau mayoritas peserta yang hadir yaitu perempuan, dan sisanya $16 \%$ yaitu laki-laki. Jadi dapat diasumsikan, guru perempuan lebih dominan tertarik pada PKM ini, dari pada guru laki-laki.

Tabel 2.

Jumlah Peserta (Responden) Berdasarkan Jenis Kelamin dan Pekerjaan

\begin{tabular}{c|c|c|c|c|c|}
\hline No & Responden & $\begin{array}{c}\text { Jenis } \\
\text { Kelamin }\end{array}$ & Pekerjaan & Jumlah Responden & Presentase \\
\hline 1. Perempuan & + & Guru & 21 & $84 \%$ \\
2. & Laki-laki & 0 & Guru & 4 & $16 \%$ \\
\multicolumn{7}{c}{ Jumlah : } & & 25 Responden & $\mathbf{1 0 0 \%}$ \\
\hline
\end{tabular}

\section{Faktor Perbedaan Persepsi}

Ternyata bukan hanya SD IA saja yang mengalami perbedaan persepsi tentang saluran komunikasi apdopsi inovasi program Adiwiyata, SD lain juga mengaku mengalami masalah yang sama. Berikut gambaran contoh perbedaan persepsi tentang saluran komunikasi apdopsi inovasi program Adiwiyata yang terjadi pada 9 SD dari 10 SD yang hadir, seperti tampak pada Tabel 3. sampai Tabel 11.

Misalnya seperti pada SDN Pondok Aren 01 Tangerang. Dari Tabel 3. dapat dipahami, masih ada perbedaan persepsi tentang cara memilah sampah dan cara menjaga kebersihan toilet, yang masih belum tuntas diatasi. 
Tabel 3.

Perbedaan Persepsi Tentang Saluran Komunikasi Apdopsi Inovasi Program Adiwiyata, Pada SDN Pondok Aren 01, Tangerang

\begin{tabular}{|c|c|c|c|}
\hline NO. & PERBEDAAN PERSEPSI & SOLUSI & HASIL \\
\hline 1 & $\begin{array}{l}\text { Tentang sampah, antara } \\
\text { siswa dan pedagang. } \\
\text { Penyebabnya karena adanya } \\
\text { sisa makanan dan minuman }\end{array}$ & $\begin{array}{l}\text { Kepala Sekolah } \\
\text { memberikan solusi yaitu, } \\
\text { membawa tempat makan } \\
\text { dan minum. }\end{array}$ & $\begin{array}{l}\text { Sampah } \\
\text { berkurang }\end{array}$ \\
\hline 2 & $\begin{array}{l}\text { Tentang toilet, antara siswa } \\
\text { dan penjaga kebersihan. } \\
\text { - Penyebabnya karena } \\
\text { kurangnya kesadaran untuk } \\
\text { menyiramnya }\end{array}$ & $\begin{array}{l}\text { Kepala Sekolah dan guru } \\
\text { memberitahukan, dan } \\
\text { mengingatkan r untuk } \\
\text { menyiram toilet } \\
\text { metelah } \\
\text { digunakan }\end{array}$ & $\begin{array}{l}\text { Belum } \\
\text { maksimal }\end{array}$ \\
\hline 3 & $\begin{array}{l}\text { Tentang sampah organic } \\
\text { dan non organic, antara } \\
\text { siswa dan para pedagang. } \\
\text { - Penyebabnya karena belum } \\
\text { bisa membedakannya. }\end{array}$ & $\begin{array}{l}\text { Kepala Sekolah dan guru } \\
\text { menyediakan tempat } \\
\text { sampah organic dan non } \\
\text { organic. }\end{array}$ & $\begin{array}{l}\text { Masih dalam } \\
\text { proses } \\
\text { pembelajaran }\end{array}$ \\
\hline
\end{tabular}

Berbeda halnya dengan SDN Pondok Aren 01 Tangerang, pada SDN Pondok Aren 02 Tangerang, seperti tampak pada Tabel 4., perbedaan persepsi yang diketahui yaitu, tentang cara membangun kepedulian, disiplin, dan dukungan, baik antara guru, Kepala Sekolah, maupun orang tua murid, yang belum ada solusinya.

Tabel 4.

Perbedaan Persepsi Tentang Saluran Komunikasi Apdopsi Inovasi Program

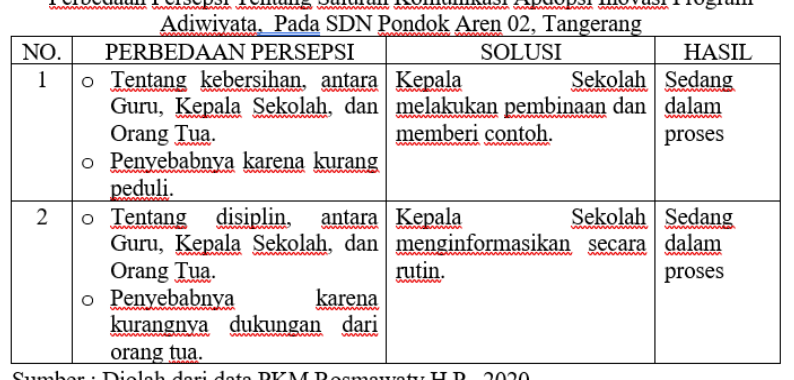

Sumber : Diolah dari data PKM Rosmawaty H.P., 2020

Sedangkan pada SDS Hikari Tangerang, seperti tampak pada dari Tabel 5., dapat dipahami, masih ada perbedaan persepsi tentang sistem pengelolaan sampah diantara murid, orang tua, dan pihak sekolah, yang belum ada solusinya.
Tabel 5 .

Perbedaan Persepsi Tentang Saluran Komunikasi Apdopsi Inovasi Program Adiwivata. Pada SDS Hikari. Tangerang

\begin{tabular}{|c|c|c|c|}
\hline NO. & PERBEDAAN PERSEPSI & SOLUSI & HASIL \\
\hline 1 & $\begin{array}{l}\text { Tentang sistem pengolahan } \\
\text { sampah, antara orang tua } \\
\text { siswa dan pihak sekolah. } \\
\text { - Penyebabnya karena } \\
\text { melibatkan peserta didik. }\end{array}$ & Belum ada & \\
\hline 2 & $\begin{array}{l}\text { - Tentang program Jumat } \\
\text { bersih. antara orang tua, } \\
\text { siswa, dan Guru. } \\
\text { - Penyebabnya karena untuk } \\
\text { meningkatkan kesadaran } \\
\text { siswa. }\end{array}$ & $\begin{array}{l}\text { Guru } \\
\text { menghadirkan } \\
\text { program Jumat } \\
\text { kreasi. }\end{array}$ & $\begin{array}{l}\text { Semua siswa tertarik } \\
\text { untuk mengikuti dan } \\
\text { menjadi lebih peduli } \\
\text { dengan sampah di } \\
\text { lingkungan sekitar }\end{array}$ \\
\hline 3 & $\begin{array}{l}\text { Tentang pemilahan sampah } \\
\text { organic dan non organic, } \\
\text { antara peserta didik dan } \\
\text { Guru. } \\
\text { - Penyebabnya karena siswa } \\
\text { belum } \\
\text { memahami sepenuhnya } \\
\text { sampah. }\end{array}$ & $\begin{array}{l}\text { Guru pendidikan } \\
\text { lingkungan hidup } \\
\text { mensosialisasikan } \\
\text { secararr terus } \\
\text { menerus kepada } \\
\text { siswa. }\end{array}$ & $\begin{array}{l}\text { Siswa lambat laun } \\
\text { mulai memaham } \\
\text { system pilah sampah } \\
\text { dan apa itu sampah } \\
\text { organic dan non } \\
\text { organic. }\end{array}$ \\
\hline
\end{tabular}

Berbeda halnya pada SDS Fadila Tangerang, seperti dapat dilihat pada Tabel 6. Perbedaan persepsi yang masih kental dirasa yaitu, tentang kantin sehat, diantara sekolah dan pihak kantin, yang belum ditemukan solusinya. Demikian halnya tentang rencana maju menjadi sekolah Adiwiyata tingkat Propinsi, juga masih ada perbedaan persepsi diantara Kepala Sekolah dan Pemilik Yayasan, yang masih belum mendapatkan dukungan finansial.

Tabel 6.

Perbedaan Persepsi Tentang Saluran Komunikasi Apdopsi Inovasi Program Adiwivata. Pada SDS Fadilah, Tangerang

\begin{tabular}{|c|c|c|c|}
\hline NO. & PERBEDAAN PERSEPSI & SOLUSI & HASIL \\
\hline 1 & $\begin{array}{l}\text { - Tentang perilaku sekolah } \\
\text { yang ramah anak (Kurasaki), } \\
\text { antara guru dan siswa. } \\
\text { - Penyebabnya karena } \\
\text { kurangnya sosialisasi dari } \\
\text { guru. }\end{array}$ & $\begin{array}{l}\text { Kepala Sekolah } \\
\text { memberikan penekanan } \\
\text { melalui sosialisasi. }\end{array}$ & $\begin{array}{l}\text { Ada kemajuan } \\
\text { walaupun } \\
\text { belum } \\
\text { maksimal. }\end{array}$ \\
\hline 2 & $\begin{array}{l}\text { - Tentang kantin sehat } \\
\text { sekolah, antara sekolah dan } \\
\text { pihak kantin. } \\
\text { - Penyebabnya karena orang } \\
\text { kantin merasa memiliki. }\end{array}$ & $\begin{array}{l}\text { Bagian kesiswaan } \\
\text { memberikan teguran } \\
\text { dan peringatan. }\end{array}$ & $\begin{array}{l}\text { Belum ada } \\
\text { kemajuan } \\
\text { yang } \\
\text { diinginkan }\end{array}$ \\
\hline 3 & $\begin{array}{l}\text { Tentang maju menjadi } \\
\text { sekolah Adiwivata tingkat } \\
\text { Provinsi, antara sekolah dan } \\
\text { Yayasan. } \\
\text { - Penyebabnya karena } \\
\text { Yayasan belum mendukung } \\
\text { secara finansial. }\end{array}$ & $\begin{array}{l}\text { Kepala Sekolah } \\
\text { mengajukan proposal. }\end{array}$ & $\begin{array}{l}\text { Masih dalam } \\
\text { proses. }\end{array}$ \\
\hline
\end{tabular}

Sumber : Diolah dari data PKM Rosmawaty H.P., 2020 
Bila melihat pada Tabel 7., maka dapat dipahami, pada Madrasah Ibtidaiyah Jam'iyyatul Khair Tangerang, masih ada perbedaan persepsi tentang cara mengurangi sampah, diantara Kepala Madrasah, pedagang, dan OB Sekolah, yang masih harus terus diingatkan.

Tabel 7.

Perbedaan Persepsi Tentang Saluran Komunikasi Apdopsi Inovasi Program Adiwivata. Pada Madrasah Ibtidaivah Jam'ivyatul Khair, Tangerang

\begin{tabular}{|c|c|c|c|}
\hline NO. & PERBEDAAN PERSEPSI & SOLUSI & HASIL \\
\hline 1 & $\begin{array}{l}\text { Tentang pengurangan } \\
\text { sampah antara guru dan } \\
\text { siswa. } \\
\text { Penyebabnya karena masih } \\
\text { Pencen } \\
\text { banyak siswa yang belum } \\
\text { membawa tumbler dan } \\
\text { tempat makan }\end{array}$ & $\begin{array}{l}\text { Kepala } r \text { Madrasah } \\
\text { menyediakan air } \\
\text { minum dan menyiapkan } \\
\text { tempat cuci tangan } \\
\text { tempat minum dan } \\
\text { tempat makannya. }\end{array}$ & $\begin{array}{l}\text { Hampir semua } \\
\text { siswa sudah } \\
\text { membawa } \\
\text { tempat minum } \\
\text { dan makan } \\
\text { sendiri }\end{array}$ \\
\hline 2 & $\begin{array}{l}\text { Tentang mengurangi } \\
\text { sampah antara sekolah dan } \\
\text { pedagang. } \\
\text { - Penyebabnya karena tidak } \\
\text { semua pedagang mau } \\
\text { mengurangi penggunaan } \\
\text { plastik. }\end{array}$ & $\begin{array}{l}\text { Kepala Madrasah dan } \\
\text { petugas Puskesmas } \\
\text { mengumpulkan para } \\
\text { pedagang }\end{array}$ & $\begin{array}{l}\text { Masih terus } \\
\text { diingatkan } \\
\text { melalui } \\
\text { komunikasi }\end{array}$ \\
\hline 3 & $\begin{array}{l}\text { Tentang mengurangi } \\
\text { sampah antara Kepala } \\
\text { Madrasah dan OB. } \\
\text { - Penyebabnya karena OB } \\
\text { harus selalu diperintah agar } \\
\text { membuat pupuk }\end{array}$ & $\begin{array}{l}\text { Kepala } \\
\text { membuat peringatan } \\
\text { pada OB di atas kertas. }\end{array}$ & $\begin{array}{l}\text { Masih terus } \\
\text { diingatkan. }\end{array}$ \\
\hline
\end{tabular}

Lain halnya pada Madrasah Ibtidaiyah Nurul Islam Tangerang, seperti tampak pada Tabel 8, perbedaan persepsi yang ada justru diantara guru dan Kepala Sekolah, tentang kesadaran membawa tumbler sendiri, yang masih dalam proses perbaikan.

Tabel 8.

Perbedaan Persepsi Tentang Saluran Komunikasi Apdopsi Inovasi Program Adiwivata. Pada Madrasah Ibtidaivah Nurul Islam, Tangerang

\begin{tabular}{|c|c|c|c|}
\hline NO. & PERBEDAAN PERSEPSI & SOLUSI & HASIL \\
\hline 1 & $\begin{array}{l}\text { Tentang mengurangi } \\
\text { sampah. antara Kepala } \\
\text { Madrasah dan guru. } \\
\text { - Penyebabnya karena masih } \\
\text { kurangnya kesadaran guru } \\
\text { membawa tumbler. }\end{array}$ & $\begin{array}{l}\text { Kepala Sekolah } \\
\text { memberikan motivasi. }\end{array}$ & $\begin{array}{l}\text { Ada } \\
\text { peningkatan. }\end{array}$ \\
\hline 2 & $\begin{array}{l}\text { Tentang mengurangi } \\
\text { sampah, antara sekolah dan } \\
\text { pedagang kantin. } \\
\text { Penyebabnya karena } \\
\text { dagangan mereka kurang } \\
\text { laris. }\end{array}$ & $\begin{array}{l}\text { Pihak sekolah } \\
\text { mengkomunikasikan }\end{array}$ & $\begin{array}{l}\text { Pedagang } \\
\text { menggunakan } \\
\text { kemasan } \\
\text { ramah } \\
\text { lingkungan }\end{array}$ \\
\hline
\end{tabular}

Sumber : Diolah dari data PKM Rosmawaty H.P., 2020

Sedangkan pada Madrasah Ibtidaiyah Nurul Huda Pd. Jaya Tangerang, seperti tampak pada Tabel 9., masih ada perbedaan persepsi tentang ecobrich dan komitmen diantara guru dan murid, yang masih dalam proses pencarian solusi, sehingga Kepala Sekolah masih harus terus menerus mengingatkan mereka semua.

Tabel 9.

Perbedaan Persepsi Tentang Saluran Komunikasi Apdopsi Inovasi Program Adiwiyata. Pada Madrasah Ibtidaiyah Nurul Huda Pd. Jaya, Tangerang

\begin{tabular}{|c|c|c|c|}
\hline NO. & PERBEDAAN PERSEPSI & SOLUSI & HASIL \\
\hline 1 & $\begin{array}{l}\text { Tentang Kurasaki, antara } \\
\text { guru dan Kepala Madrasah } \\
\text { - Penyebabnya karena } \\
\text { pemahaman yang belum } \\
\text { mendalam. }\end{array}$ & $\begin{array}{ll}\text { Kepala } & \text { Madrasah } \\
\text { mengadakan rapat dan } \\
\text { melakukan } & \text { sosialisasi } \\
\text { lagi. } & \end{array}$ & Lebih baik \\
\hline 2 & $\begin{array}{l}\text { - Tentang ecobrich, antara } \\
\text { guru dan anak murid. } \\
\text { - Penyebabnya karena kurang } \\
\text { siap. }\end{array}$ & $\begin{array}{l}\text { Kepala Madrasah terus } \\
\text { mengingatkan. }\end{array}$ & $\begin{array}{l}\text { Masih terus } \\
\text { berproses }\end{array}$ \\
\hline 3 & $\begin{array}{l}\text { O Tentang kata-kata } \\
\text { "sampahku } \\
\text { tanggungjawabku", antar } \\
\text { anak murid. } \\
\text { ana Penyebabnya karena belum } \\
\text { komitmen. }\end{array}$ & $\begin{array}{l}\text { Guru terus saling } \\
\text { mengingatkan. }\end{array}$ & $\begin{array}{l}\text { Masih terus } \\
\text { berproses }\end{array}$ \\
\hline
\end{tabular}

Sumber : Diolah dari data PKM Rosmawaty H.P., 2020

Adapun pada SDN Pondok Karya Tangerang, dilihat dari Tabel 10. dapat dipahami, masih ada perbedaan persepsi tentang penggunaan plastik di kantin sekolah, dan cara menjaga kebersihan toilet diantara anak murid, yang masih belum dapat diatasi.

Tabel 10.

Perbedaan Persepsi Tentang Saluran Komunikasi Apdopsi Inovasi Program

\begin{tabular}{|c|c|c|c|}
\hline \multicolumn{4}{|c|}{ Adiwiyata, Pada SDN Pondok Karya, Tangerang } \\
\hline NO. & PERBEDAAN PERSEPSI & SOLUSI & HASIL \\
\hline 1 & $\begin{array}{l}\text { - Tentang sampah antar } \\
\text { siswa. } \\
\text { - Penyebabnya karena adanya } \\
\text { limbah atau sisa makan } \\
\text { kantin }\end{array}$ & $\begin{array}{l}\text { Membawa tempat } \\
\text { makan untuk siswa. }\end{array}$ & $\begin{array}{l}\text { Sampah } \\
\text { berkurang }\end{array}$ \\
\hline 2 & $\begin{array}{l}\text { - Tentang ketersediaan plastic } \\
\text { dan kertas di kantin antara } \\
\text { kantin dan sekolah. } \\
\text { - Penyebabnya karena jajanan } \\
\text { dengan } \\
\text { wadah/tempat/bungkus. }\end{array}$ & $\begin{array}{l}\text { Tidak menyediakan } \\
\text { wadah/tempat plastic } \\
\text { sebagai } \\
\text { jajanan. }\end{array}$ & $\begin{array}{l}\text { Masih belum } \\
\text { maksimal. }\end{array}$ \\
\hline 3 & $\begin{array}{l}\text { - Tentang kebersihan toilet, } \\
\text { antar anak murid. } \\
\text { - Penyebabnya karena belum } \\
\text { ada kesadaran menyiram } \\
\text { setelah menggunakan }\end{array}$ & $\begin{array}{l}\text { Memberi contoh, } \\
\text { mengajarkan, dan kerja } \\
\text { bakti membersihkan } \\
\text { toilet }\end{array}$ & $\begin{array}{l}\text { Masih belum } \\
\text { maksimal }\end{array}$ \\
\hline
\end{tabular}

Demikian halnya pada SD Islam Plus Baitul Maal Tangerang, seperti dilihat pada Tabel 11, perbedaan persepsi yang tampak mirip dengan perbedaan persepsi pada SDN Pondok Karya 
Tangerang, yaitu tentang penggunaan plastik di kantin sekolah, dan cara menjaga kebersihan toilet diantara anak murid, yang masih belum dapat maksimal diatasi.

Tabel 11.

Berbedaan Persepsi Tentang Salutan Komunikasi Apdonsi Inouasi Program

\begin{tabular}{|c|c|c|c|}
\hline No. & PERBEDAAN PERSEPSI & SOLUSI & HASIL \\
\hline 1 & $\begin{array}{l}\text { - Tentang sampah antax } \\
\text { gisura. } \\
\text { - Renxebabnaxa kaxena adanxa } \\
\text { limbah atau sisa. makan } \\
\text { kantin }\end{array}$ & $\begin{array}{l}\text { Membawa tempat } \\
\text { makan untuk siswa. }\end{array}$ & $\begin{array}{l}\text { Sampah } \\
\text { berkurang }\end{array}$ \\
\hline 2 & 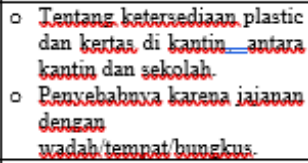 & $\begin{array}{lr}\text { Jidlak menxediakan } \\
\text { wadabitempat plastic } \\
\text { sebagai } \\
\text { jaianan. }\end{array}$ & $\begin{array}{l}\text { Masih belum } \\
\text { maksimal. }\end{array}$ \\
\hline 3 & $\begin{array}{l}\text { - Tentang kebersibas toilet, } \\
\text { antar anak murid. } \\
\text { - Penxebabnwa karena belum } \\
\text { ada keradaran menvicam } \\
\text { getelah menggunakan. }\end{array}$ & $\begin{array}{l}\text { Memberi squtoh } \\
\text { mengajarkan, dan keria } \\
\text { bakti membersihkan } \\
\text { toilet }\end{array}$ & $\begin{array}{l}\text { Masih belum } \\
\text { maksimal }\end{array}$ \\
\hline 4 & $\begin{array}{l}\text { - Tentang pengertian } \\
\text { Adiuivata (apa dan } \\
\text { bagaimana), antar guru. } \\
\text { - Renwebabmwa bareva kurang } \\
\text { informasi. } \\
\end{array}$ & $\begin{array}{lr}\text { Kenala } & \text { Sekolah } \\
\text { mengadakan } & \text { rapat } \\
\text { bcordinasi. } & \end{array}$ & $\begin{array}{l}\text { Sudah ada } \\
\text { keramaan } \\
\text { persemsi. }\end{array}$ \\
\hline 5 & 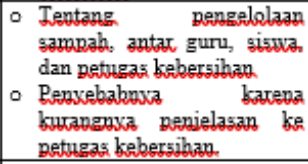 & $\begin{array}{lr}\text { Kenala } & \text { Selolah } \\
\text { mengadakan pelatihan } \\
\text { pemilahan gampah. }\end{array}$ & $\begin{array}{l}\text { Sudah ada } \\
\text { tempat } \\
\text { sampah } \\
\text { organic dan } \\
\text { non organic. }\end{array}$ \\
\hline 6 & 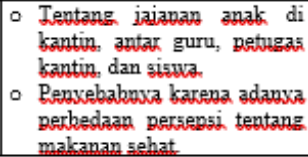 & $\begin{array}{l}\text { Lembaga memberi } \\
\text { pemabaman ke petugas } \\
\text { bantin dan siswa. }\end{array}$ & $\begin{array}{l}\text { Renxediaan } \\
\text { makanan yang } \\
\text { lebih sehat. }\end{array}$ \\
\hline
\end{tabular}

Sumber : Diolah dari data PKM Rogmawaty H.P., 2020

Demikian antara lain contoh perbedaan persepsi tentang saluran komunikasi apdopsi inovasi program Adiwiyata yang berhasil dijaring dari beberapa peserta PKM yang hadir, tidak termasuk dari SD IA.

\section{Respon Atas Materi Yang Disampaikan}

Untuk mengetahui respon atas materi yang disampaikan, dibagikan kuesioner dengan tiga jenis pertanyaan. Pertama, tentang perhatian dan ketertarikan peserta, lalu tentang pengertian peserta, dan ketiga tentang penerimaan peserta akan isi pesan yang disampaikan. Namun tidak semua peserta memberikan jawaban sebagaimana diharapkan.

Seperti tampak pada Tabel 12., diketahui ada satu peserta yang tidak memberikan jawaban, dan ada satu peserta yang menyatakan bahwa diskusi yang sudah dilakukan kurang menarik, karena kurang variasi.

Tabel 12.

Tingkat Perhatian dan Ketertarikan Peserta Akan Isi Pesan

\begin{tabular}{|c|c|c|c|c|c|c|}
\hline \multirow{2}{*}{ No } & \multirow{2}{*}{ Pernyataan } & \multicolumn{2}{|c|}{ Jumlah Respon } & \multicolumn{2}{|c|}{ Presentase (\%) } & \multirow{2}{*}{$\frac{J u m l a h}{(\%)}$} \\
\hline & & $\mathrm{Ya}$ & Tidak & $\mathrm{Ya}$ & Tidak & \\
\hline 1. & $\begin{array}{l}\text { Materi dan penjelasan yang } \\
\text { disampaikan menarik perhatian }\end{array}$ & 25 & 0 & 100 & 0 & $100 \%$ \\
\hline 2. & $\begin{array}{l}\text { Solusi yang disampaikan menarik } \\
\text { perhatian }\end{array}$ & 25 & 0 & 100 & 0 & $100 \%$ \\
\hline 3. & $\begin{array}{l}\text { Diskusi yang sudah dilakukan } \\
\text { menarik }\end{array}$ & 23 & 1 & 92 & 4 & $96 \%$ \\
\hline 4. & $\begin{array}{l}\text { Pelatihan yang sudah dilakukan } \\
\text { menarik }\end{array}$ & 25 & 0 & 100 & 0 & $100 \%$ \\
\hline & Rata-rata : & 24,5 & 0,25 & 98 & 1 & $99 \%$ \\
\hline
\end{tabular}

Berbeda halnya dengan pengertian peserta terhadap isi pesan, seperti tampak pada Tabel 13. Ada 6 peserta atau sekitar $24 \%$ peserta yang memberikan jawaban tidak mengerti. Misalnya saja tentang ruang komunikasi bagi keterbukaan anak murid, orang tua, maupun guru, dan juga tentang metode komunikasi guru dalam menggali informasi dari anak murid, orang tua, maupun guru sendiri, sebagai cara evaluasi mengenai pilihan saluran komunikasi adopsi inovasi program Adiwiyata. Demikian halnya tentang praktek komunikasi yang sudah dilakukan. Ada 2 orang peserta atau sekitar $8 \%$ yang masih belum mengerti. Sedangkan tentang metode komunikasi fact fainding sebagai cara untuk menggali informasi dari anak murid, orang tua, maupun guru sendiri, masih belum dimengerti oleh 1 orang peserta atau sekitar $4 \%$ saja. Jadi artinya, mayoritas atau $76 \%$ peserta menyatakan mengerti dan bahkan dapat menyebutkan paling sedikit 3 contoh metode komunikasi fact fainding, seperti observasi, survey, maupun wawancara. 


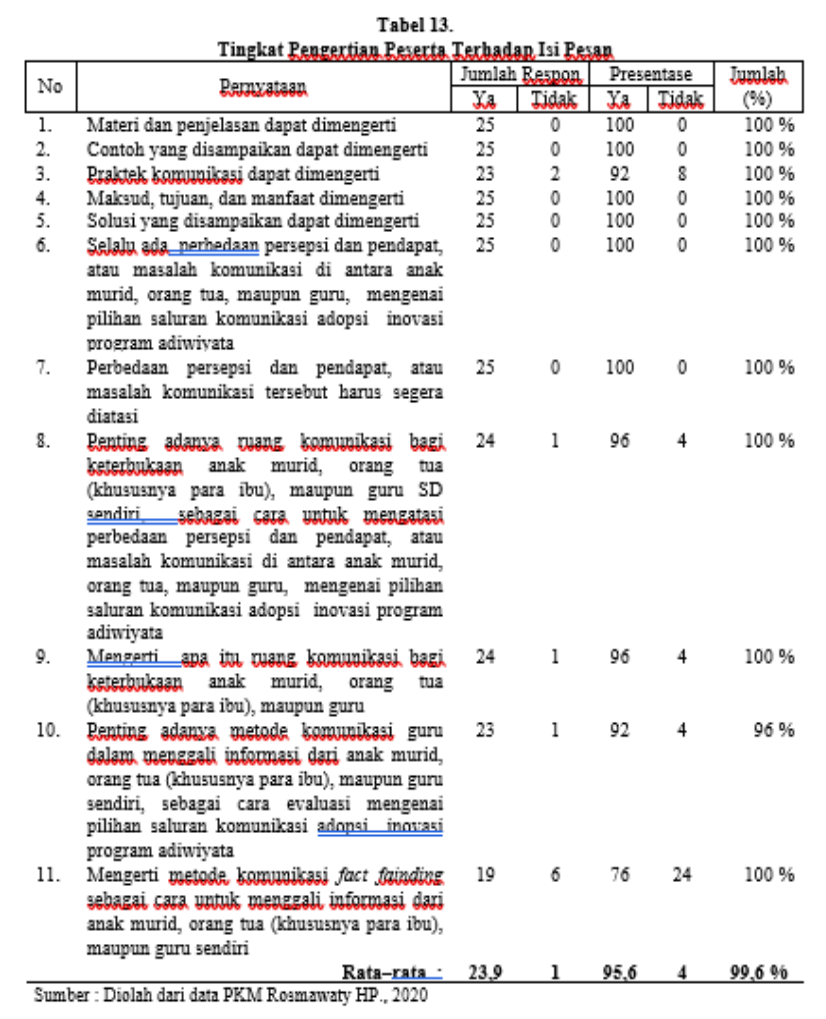

Jadi, bila melihat Tabel 13. dapat diketahui, mayoritas atau 99,6 \% peserta PKM menyatakan, mengerti isi pesan yang disampaikan, dan $4 \%$ menyatakan belum mengerti. Sisanya, 0,4\% tidak memberikan pernyataan.

Setelah melihat dan mengukur respon peserta tentang isi pesan, berikutnya juga dilakukan pengukuran tentang penerimaan peserta terhadap isi pesan, seperti tampak pada Tabel 14. Dari Tabel 14. dapat dipahami, mayoritas peserta atau sekitar 93,8 $\%$ menyatakan dapat menerima, dan hanya sekitar $0,7 \%$ saja yang tidak dapat menerima. Selebihnya atau 5,5\% diketahui tidak menjawab kuesioner yang diberikan.

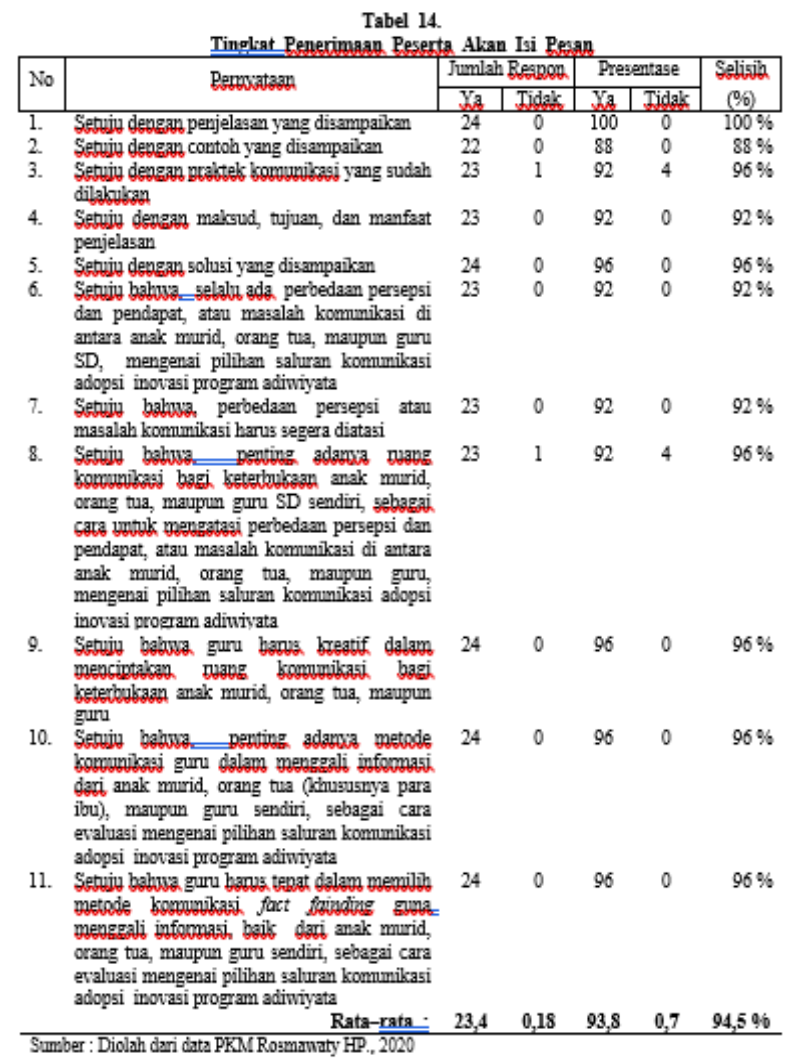

\section{Pembahasan}

Pembahasan pertama yaitu, mengenai perbedaan persepsi. Menurut Gibson dan Donnelly (1996, p.134) dalam Rosmawaty (2010, p.63), persepsi merupakan proses kognitif yang dialami setiap orang dalam memahami lingkungannya, baik lewat penglihatan, pandangan, penghayatan, perasaan, maupun penciuman. Hal inipun terjadi pada SD IA dan semua SD binaan IA, baik tentang program Adiwiyata, cara mengurangi penggunaan plastik dan sampah sisa makanan dan minuman, juga tentang cara menjaga kebersihan toilet, sebagaimana tampak pada Tabel 4.2. sampai Tabel 4.10. Jadi artinya, perbedaan persepsi tersebut merupakan hal yang wajar terjadi, dikarenakan adanya perbedaan proses kognitif dalam memahami lingkungan, sebagai akibat adanya perbedaan cara pandang, penghayatan, perasaan, maupun penciuman.

Pembahasan kedua yaitu, tentang rata-rata tingkat respon peserta akan isi pesan PKM yang 
dijaring melalui kuesioner. Bila melihat Tabel 12. sampai Tabel 14., dapat dipahami bahwa, tingkat perhatian dan ketertarikan peserta, hanya mencapai $98 \%$ saja, karena memang sejak awal ada satu peserta yang tidak mengisi kuesioner yang diberikan. Demikian halnya dengan tingkat pengertian peserta, juga tidak mencapai $100 \%$, hanya mencapai $95,6 \%$ saja. Selain karena ada $4 \%$ peserta yang menyatakan tidak mengerti, juga ada 0,4 peserta yang tidak menjawab kuesioner yang diberikan. Persentase ini jelas lebih kecil dari pada tingkat perhatian dan ketertarikan peserta. Begitupun tentang tingkat penerimaan peserta akan isi pesan, juga semakin kecil, hanya $93,8 \%$ saja. Selain karena ada $0,7 \%$ peserta yang menjawab tidak, juga ada $5,5 \%$ peserta yang tidak memberikan jawaban.

Jadi artinya, selain ada penurunan respon positif, juga ada penurunan jumlah responden yang berkenan mengisi kuesioner evaluasi yang diberikan, seperti tampak pada Tabel 4.14. Meski demikian, mayoritas atau rata-rata $95,8 \%$ peserta pelatihan PKM masih punya perhatian dan ketertarikan, juga mengerti dan menerima isi pesan PKM ini, seperti dapat dilihat pada Tabel 15. Jadi artinya, pelatihan PKM ini tetap menarik perhatian, bisa dimengerti, dan dapat dipahami.

Tabel 15.

Tingkat Respon Peserta Terhadap Isi Pesan PKM

\begin{tabular}{|c|c|c|c|c|c|}
\hline \multirow{3}{*}{ No } & \multirow{3}{*}{$\frac{\text { Respon Peserta Terhadap }}{\text { Isi Pesan PKM }}$} & \multirow{2}{*}{\multicolumn{3}{|c|}{ Rata-Rata Respon (\%) }} & \multirow{3}{*}{$\frac{\frac{\text { Jumlah }}{\text { Respon }}}{(\%)}$} \\
\hline & & & & & \\
\hline & & $\underline{\mathrm{Ya}}$ & $\underline{\text { Tidak }}$ & Tidak Menjawab & \\
\hline 1. & Tingkat perhatian dan ketertarikan & 98 & 1 & 1 & 99 \\
\hline 2. & Tingkat pengertian & 95,6 & 4 & 0,4 & 99,6 \\
\hline \multirow[t]{2}{*}{3.} & Tingkat penerimaan & 93,8 & 0,7 & 5,5 & 94,5 \\
\hline & Rata-rata : & 95,8 & 1,9 & 2,3 & 97,7 \\
\hline
\end{tabular}

Sumber : Diolah dari data PKM Rosmawaty HP., 2020

Pembahasan ketiga yaitu, tentang faktor perbedaan persepsi mengenai pilihan saluran komunikasi adopsi inovasi program Adiwiyata. Menurut Mulyana (2008, p.171-175) dalam Rosmawaty (2010, p.63), adapun faktor yang dapat menyebabkan terjadinya perbedaan persepsi yaitu, selain karena adanya perbedaan persepsi terhadap objek (lingkungan fisik), juga karena adanya perbedaan persepsi terhadap manusia (persepsi sosial). Namun pada PKM ini, sebagaimana tampak pada Tabel 4.3. sampai Tabel 4.11., dapat dipahami, ada sekitar 9 faktor penyebab perbedaan persepsi tentang saluran komunikasi apdopsi inovasi program
Adiwiyata seperti, faktor manusia, faktor kesadaran dan peduli, faktor komitmen, faktor ketidaksiapan, faktor perilaku, faktor informasi, faktor pengetahuan, faktor pelatihan, dan faktor keuangan.

Demikian antara lain 9 faktor penyebab perbedaan persepsi tentang saluran komunikasi apdopsi inovasi program Adiwiyata pada beberapa SD yang hadir dalam acara PKM ini. Untuk mempermudah dan mempercepat pemahaman bersama, digunakan alat bantu visual seperti tampak pada Gambar 2. sebagai berikut :

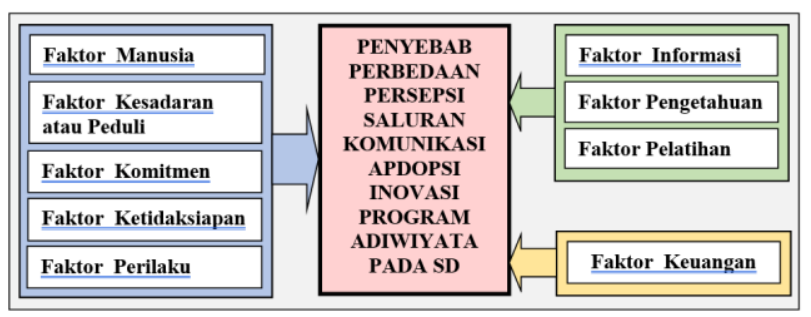

Gambar 2. Faktor Penyebab Perbedaan Persepsi Tentang

Saluran Komunikasi Apdopsi Inovasi Program Adiwiyata Pada SD di Tangerang Sumber: Hasil Olah Pikir Rosmawaty Hilderiah Pandjaitan, 2020)

\section{KESIMPULAN}

Pada akhirnya dapat disimpulkan, Program Pengabdian Kepada Masyarakat Magister Ilmu Komunikasi Universitas Mercu Buana (PKM UMB) dengan tema, pelatihan komunikasi mengatasi perbedaan persepsi tentang pilihan saluran komunikasi adopsi inovasi program adiwiyata pada anak murid, orang tua, dan guru Sekolah Dasar Islam Amalina di Tangerang Selatan, yaitu sebagai berikut : Pertama, pelatihan ini berhasil menarik perhatian, dimengerti, dan diterima oleh mayoritas peserta PKM, yang semuanya berprofesi sebagai guru pada tingkat SD, meski tidak semua peserta bersedia mengisi kuesioner secara lengkap.; Kedua, perbedaan persepsi terjadi pada semua SD yang ikut dalam PKM ini. Baik antar guru dengan kepala sekolah, juga dengan murid, orang tua murid, petugas kebersihan sekolah, pemilik Yayasan Sekolah, maupun dengan pedagang di kantin sekolah. Umumnya tentang program Adiwiyata, cara mengurangi penggunaan plastik dan sampah sisa makanan dan minuman, juga tentang cara menjaga kebersihan toilet. Jadi dapat disimpulkan, PKM ini bermanfaat bagi semua peserta, karena memberikan 
pemahaman baru tentang cara komunikasi dalam mengatasi perbedaan persepsi mengenai pilihan saluran komunikasi adopsi inovasi program adiwiyata.; Ketiga, dapat disimpulkan ada sekitar 9 faktor penyebab perbedaan persepsi tentang saluran komunikasi apdopsi inovasi program Adiwiyata seperti, faktor manusia, faktor kesadaran dan peduli, faktor komitmen, faktor ketidaksiapan, faktor perilaku, faktor informasi, faktor pengetahuan, faktor pelatihan, dan faktor keuangan.; Keempat, cara komunikasi mengatasi perbedaan persepsi mengenai pilihan saluran komunikasi adopsi inovasi program adiwiyata pada murid, orang tua, dan guru masih kurang variatif, dan cenderung dilimpahkan atau menjadi tanggungjawab kepala sekolah semata. Jadi artinya, menurut mayoritas peserta yang hadir, pada SD mereka, masih a banyak pihak yang belum peduli pada tanggungjawab bersama dan upaya mencari variasi cara komunikasi dalam mengatasi perbedaan persepsi yang ada. Dengan demikian dapat disimpulkan, PKM ini bermanfaat bukan hanya bagi SD IA, tetapi juga bagi semua SD binaan SD IA.

\section{UCAPAN TERIMAKASIH}

Ucapan terimakasih disampaikan kepada Lembaga Pengabdian Pada Masyarakat (LPPM) Universitas Mercu Buana dan Sekolah Dasar Islam Amalina di Tangerang Selatan, atas segala dukungan yang telah diberikan, sehingga acara PKM ini dapat terlaksana.

\section{REFERENSI}

Alwi, Idrus. (2015), Kriteria Empirik Dalam Menentukan Ukuran Sampel Pada Pengujian Hipotesis Statistika dan Analisis Butir, Jurnal Formatif 2(2): 140-148, ISSN: 2088-351X, diakses dari https://media.neliti.com/media/publications/ 234836-kriteria-empirik-dalam-menentukan-ukuran -60ddb857.pdf

\footnotetext{
Campbell, David. (2017). Mengembangkan Kreativitas, Diterjemahkan oleh A.M. Mangunhardjana. Yogyakarta: PT. Kanisius.
}

Hadi, Djati Witjaksono (2019), 434 Sekolah Raih Penghargaan Adiwiyata Tahun 2019, Siaran Pers PPID Kementerian Lingkungan Hidup dan Kehutanan (KLHK), Jumat, 13 Desember 2019. Nomor: $\quad$ SP. 512/HUMAS/PP/HMS.3/12/2019Desember 2019. diakses dari

https://ppid.menlhk.go.id/siaran pers/browse/2254

Hidayati, Nanik (2013), Perilaku Warga Sekolah Dalam Program Adiwiyata di SMK Negeri 2 Semarang, ejournal UNDIP, diakses dari http://eprints.undip.ac.id/40663/

Iswari, Rizky Dewi dan Suyud W. Utomo, (2017), Evaluasi Penerapan Program Adiwiyata Untuk Membentuk Perilaku Peduli Lingkungan di Kalangan Siswa (Kasus: SMA Negeri 9 Tangerang Selatan dan MA Negeri 1 Serpong), Jurnal Ilmu Lingkungan, Volume 15 Issue 1 (2017) : 35-41, ISSN 1829-8907, diakses dari https://media.neliti.com/media/publications/101566ID-evaluasi-penerapan-program-adiwiyata-unt.pdf

Kriyantono, Rachmat. (2007). Teknik Praktis Riset Komunikasi. Jakarta:Kencana

Mulyana, Deddy. (2008). Ilmu Komunikasi. Bandung : Remaja Rosdakarya

Munandar, Utami. (2004). Mengembangkan Bakat Dan Kreativitas Anak Sekolah. Jakarta : Gramedia Widiasarana

Neuman, W. Lawrance (2013, edisi 7). Metodologi Penelitian Sosial : Pendekatan Kualitatif dan Kuantitatif, Penerbit P.T Indeks, Jakarta

Pandjaitan, Rosmawaty Hilderiah., dan Yoyoh Hereyah, Suratani Bangko, dan Maria Pertiwi, (2019). Ragam saluran Komunikasi Adopsi Program Adiwiyata Pada Anak Murid, Orang Tua, dan Guru SD Islam Amalina Di Tangerang Selatan, Prosiding Konferensi Pendidikan Nasional Strategi Dan Implementasi Pendidikan Karakter Pada Era Revolusi Industri 4.0, ISSN : 2654-8607, p. 248-259, Vol 2, No 1 (2020), Fakultas Keguruan dan Ilmu Pendidikan Universitas Mercu Buana Yogyakarta, diakses dari https://ejurnal.mercubuana- 
yogya.ac.id/index.php/

Prosiding_KoPeN/article/view/1108.

Rogers, Everett M. (1995). Diffusion of Innovations, Fourth Edition, The Free Press, New York

Rosmawaty HP., (2010), Mengenal Ilmu Komunikasi, Bandung : P.T Widya Padjadjaran

Simamora, Henry. (2003), Manajemen Sumber Daya Manusia. Edisi kedua, Yogyakarta : STIE YKPN
Sugiyono (2013), Metode Penelitian Kombinasi, Bandung, Alfabeta

Gibbons, Zeynita dan Ruslan Burhani (2016), UNESCO Dakar Puji Program Sekolah Adiwiyata Indonesia, London (Antara News) (2016). diakses dari https://www.antaranews.com/ berita/598742/unesco-dakar-puji-program-sekolahadiwiyata-indonesia, berita 29 November 2016, diakses pada tanggal 25 Januari 2020, pk. 2:09 wib. 